\title{
The Position and Responsibility of Sharia Supervisory Board in The Company Organs
}

\author{
Hidayatulloh \\ Syarif Hidayatullah \\ State Islamic University Jakarta, Indonesia \\ hidayatulloh87@uinjkt.ac.id
}

\begin{abstract}
The existence of Sharia Supervisory Board in Sharia Financial Institution which has a legal entity as a company is a mandate of legislation and to keep the trust of sharia financial consumers. In fact, Sharia Supervisory Board who works in Sharia Financial Institution does not have any clear post and responsibility based on Act Number 40 Year 2007 in Limited Company, Act Number 21 Year 2008 in Sharia Banking and others related legislations. In addition, they were assumed as a financial burden because every company based on Sharia Principles must own Sharia Supervisory Board. This paper will analyze these problems using normative legal method with legal approach. The result of this paper will offer idea and legal thoughts in order to place Sharia Supervisory Board into company organs. Furthermore, Sharia Financial Institution as a company should work effectively and efficiently to get the best profit based on Sharia Principles.
\end{abstract}

Keywords-Sharia Supervisory Board; Company Organs; Sharia Financial Institution;

\section{INTRODUCTION}

Sharia principle is one of the characteristics of Sharia Financial Institution (SFI) which is different from conventional financial institution. In addition, SFI applies Islamic or sharia principle which is the primary distinction of sharia financial instructions in its business activities. Sharia principle is the Islamic law principles in the banking business or other financial institution based on the fatwa issued by an institution having the authority in stipulating fatwa in sharia matters (Sharia Banking Act, Indonesia Number 21, 2008).

SFI must follow sharia principle based on the fatwa issued by Indonesian Ulama Council. Every SFI appoints Sharia Supervisory Board (SSB) as the representative of Indonesian Ulama Council to make sure that all business activities do not violate sharia principle.

SSB is a board whose tasks are to provide advices and recommendations to the Board of Directors as well as to monitor Bank activities so that they are in line with sharia principles (BI Sharia Commercial Bank Regulation, Number 11/3/PBI, 2009).

This paper will analyze the position and responsibility of SSB in Company Organs based on Act Number 40 Year 2007 in Limited Company, Act Number 21 Year 2008 in Sharia
Banking and others related legislations. Because of those unclear points, SSB does not have an equal position with the Board of Commissioner and the Board of Director in company organs.

Sharia financial institution can be divided, according to its legal identity, into limited liability company (perseroan terbatas), commanditaire vennootschap, cooperative (koperasi) and others.

\section{METHOD AND MATERIALS}

This paper is a normative legal research which concerns with the formulation of legal doctrines through the analysis of legal rules. The researcher uses secondary data by reviewing documented information in the form of Laws, regulation, books, scientific papers and research results. The process of analyzing data uses qualitative approach that emphasizes the meaning, context and perspective of the native point of view.

The research also explores the meaning and notion of Laws and Regulations which regulate SSB in Indonesia. With the aim of achieving conclusions, the research compares Laws and Regulations using theoretical legal approach. Furthermore this paper describes some conclusions to get useful recommendations.

There are quite significant numbers of studies that discussed about SSB in different perspective and approaches. For instance, Malek Marwan Yousef Injas, Mohamad Sabri Haron, Rashila Ramli and Raghad Azzam Injas (2016) explained the impact of SSB on the Islamic bank stability. The researchers assumed that SSB is a significant department in the Islamic bank like other departments. The interference of it decision-making and management could adversely affect for the Islamic bank.

Hussein M. Rababa'ah and Yousuf Muhammad Rababa'ah (2016) study the significance of the concept of the Islamic law, or Sharia supervision of the Jordan Islamic Bank. There are two bodies of the Islamic supervision in the bank: the SSB and the internal auditing department who help and assist the Islamic supervisory board to supervise banking business and services. They are really important because of their legitimation of sharia understanding. In addition, many 
staffs of the banks are not familiar with the Islamic law provisions as well as the principles of the banking Islamic services.

Waeibrorheem Waemustafa and Azrul Abdullah (2014) examined the relationships between the effectiveness of SSB, their remuneration and mode of financing Islamic bank. They compared 18 (eighteen) Islamic banks in Malaysia from the year 2012 to 2013 as samples. The research finding reveals that an effective Shariah Supervisory Board does not have significant bearing towards the choice of Islamic mode of financing in Malaysia but their remuneration has.

\section{RESUlt AND DiscUSSION}

\section{A. Sharia Supervisory Board in Indonesian Law}

It is essential to know about the law which regulates Sharia Supervisory Board, as it will help us to understand the legal position of it. Here are the Laws which become a legal basis of Sharia Supervisory Board in Indonesia:

\begin{tabular}{|c|c|c|}
\hline NO & LAW & ARTICLE \\
\hline 1 & $\begin{array}{l}\text { The Act of The Republic of } \\
\text { Indonesia Number } 21 \text { Year } 2008 \\
\text { on Sharia Banking }\end{array}$ & $\begin{array}{c}\text { Article } 32 \\
\text { (1) A Sharia Supervisory } \\
\text { Board must be established in a } \\
\text { Sharia (Islamic) Bank and } \\
\text { Conventional } \\
\text { Commercial Bank having } \\
\text { UUS. }\end{array}$ \\
\hline 2 & $\begin{array}{l}\text { The Act of The Republic of } \\
\text { Indonesia Number } 40 \text { Year } 2007 \\
\text { on Limited Liability Company }\end{array}$ & $\begin{array}{l}\text { Article } 109 \\
\text { (1) The Company having } \\
\text { its business activities based on } \\
\text { then sharia principle, other } \\
\text { than having a Board of } \\
\text { Commissioners, shall also be } \\
\text { obliged to have Sharia } \\
\text { Supervisory Board. }\end{array}$ \\
\hline 3 & $\begin{array}{c}\text { The Act of The Republic of } \\
\text { Indonesia Number } 40 \text { Year } 2014 \\
\text { on Insurance }\end{array}$ & $\begin{array}{c}\text { Article } 8 \\
\text { (2) To acquire the } \\
\text { business license as referred to } \\
\text { in paragraph (1), the } \\
\text { requirements listed } \\
\text { below must be fulfilled: } \\
\text { g. the fit and proper } \\
\text { requirements of the board of } \\
\text { directors and board of } \\
\text { commissioners, or the } \\
\text { equivalent to the board of } \\
\text { directors and board } \\
\text { of commissioners in a } \\
\text { legal entity in the form of } \\
\text { cooperative or mutual } \\
\text { company as referred to in } \\
\text { Article } 6 \text { paragraph (1) letter c, } \\
\text { the sharia } \\
\text { supervisory board, } \\
\text { auditor; }\end{array}$ \\
\hline
\end{tabular}

\begin{tabular}{|c|c|c|}
\hline 4 & $\begin{array}{c}\text { Financial Services } \\
\text { Authorities Rule Number } 15 \text { Year } \\
2015 \text { on Implementation of Sharia } \\
\text { Principles in the Capital Market }\end{array}$ & $\begin{array}{l}\text { Article } 7 \\
\text { Each Party conducting } \\
\text { Sharia Activities in the Capital } \\
\text { Market as referred to in Article } \\
4 \text { letter a shall: } \\
\text { a. declare in the } \\
\text { articles of association or } \\
\text { similar document that its } \\
\text { business activities are } \\
\text { conducted on the basis of } \\
\text { Sharia Principles in the Capital } \\
\text { Market; and } \\
\text { b. have a Sharia } \\
\text { Supervisory Board. }\end{array}$ \\
\hline 5 & $\begin{array}{c}\text { Bank Indonesia Regulation } \\
\text { Number: 11/3/PBI/2009 } \\
\text { Concerning } \\
\text { Sharia Commercial Bank }\end{array}$ & $\begin{array}{l}\text { Article } 34 \\
\text { (1) A Bank is obliged } \\
\text { to establish DPS which } \\
\text { domiciles at the head office of } \\
\text { the Bank. }\end{array}$ \\
\hline 6 & $\begin{array}{c}\text { Circular Letter of Bank } \\
\text { Indonesia Number } 15 / 22 / \mathrm{DPbS} \\
2013 \text { to All Sharia Rural Banks in } \\
\text { Indonesia on Guidelines for the } \\
\text { Implementation of Duties and } \\
\text { Responsibilities of the Sharia } \\
\text { Supervisory Board of Sharia } \\
\text { Rural Bank. }\end{array}$ & $\begin{array}{l}\text { All articles explain about } \\
\text { duties and responsibilities of } \\
\text { Sharia Supervisory Board. }\end{array}$ \\
\hline
\end{tabular}

From the Laws above, it can be concluded that Sharia Supervisory Board must be established by all sharia financial institutions in Indonesia. Hence, its position is legally clear and explicitly regulated by Indonesian Law. In addition, the existence of Sharia Supervisory Board is a special treatment for institutions or companies which have business comply with sharia principle beside they have Board of Commissioner as the supervisor.

When the Laws have regulated the position of Sharia Supervisory Board, it can be understood that supervision based on sharia principle is very important for more than one reason: First, the rationale for establishing sharia banks and other sharia financial institutions are introducing a legal substitute for the usury that is illegal from an Islamic perspective. Because the Sharia Supervisory Board is the body that watches, monitors and puts the work of financial institutions and their compliance with the Islamic law provisions under surveillance.

Second, at present, banking and other financial institutions have various complicated forms with the widespread of new transaction gadgets such as credit cards, various kinds of accounts, and electronic dealings that have no relevant stipulations in the old references of the Islamic law.

Third, the banking and other financial institution operations in investments, financing, in particular require the opinion of the Sharia Supervisory Board, because these operations and business activities are changing constantly. Therefore, the staffs of sharia financial institution need to keep in touch with the Sharia Supervisory Board for getting the proper fatwa (legal opinion) related to the unprecedented cases they face during work. 
Fourth, the presence of the Sharia Supervisory Board gives the financial institution an Islamic character which gives Muslim customers a sense of satisfaction and confidence (Hussein M. Rababa'ah and Yousuf Muhammad Rababa'ah, 2016).

\section{B. The Responsibility of Sharia Supervisory Board}

SSB has great responsibility to supervise and make certain that every activity in sharia financial institutions follow sharia principle. In order to understand it, we have to explore and find some separate Laws and Regulations about sharia financial institutions.

The execution of SSB's task and responsibility among others: (1) assessing and ensuring fulfillment of Sharia Principles on operational guidelines and products issued by Bank; (2) supervising development process of Bank new products; (3) obtaining fatwa (decrees) from the National Sharia Board for Bank new products that do not yet have fatwa; (4) periodically conducting reviews of fulfillment of sharia principles on the mechanisms of fund accumulation and fund channeling as well as bank service provisions; and (5) requesting data and information related to sharia aspects from Bank work units in the framework of executing its tasks (BI Sharia Commercial Bank Regulation, Number 11/3/PBI, 2009).

In sharia capital market, SSB is Sharia Capital Market Expert who has certified and obtained permission by Financial Services Authorities/OJK. SSB's duties, responsibilities and authorities are: (1) giving advises and suggestions to Board of Directors and Board of Commissioner in the company about Sharia Principle in Capital Market; (2) overseeing sharia compliance of company business activities in Capital Market; (3) reviewing sharia compliance of company business activities in Capital Market periodically; (4) giving written warning to Director of company at the outside of 2 (two) weekdays after found deviation and asking him to make improvements at the latest 10 (ten) weekdays after accepted that written warning, with sending a copy to Financial Services Authorities/OJK and Board of Board of Commissioner; (5) keeping the secret of company document, data and information which are supervised and given advice; (6) asking data and information to company in order to supervise the implementation of Sharia Compliance in Capital Market; (7) accompanying or representing the company in discussion with National Sharia Board of Indonesian Ulama Council; and (8) giving sharia compliance statement to Sharia Principle in Capital Market on products or services in Capital Market (OJK Sharia Capital Market Expert Rule, Number 16, 2015).

\section{Comparison between Sharia Supervisory Board and Board of Commissioners in Company Organs}

Company Organs means the General Meeting of Shareholders, the Board of Directors, and the Board of Commissioner (Limited Liability Company Act, Indonesia Number 40, 2007). From this definition, SSB is not a part of Company Organs. As stated by Gatot Supramono, SSB is not a part of Company Organs although having supervisory function as well as Board of Commissioners. Their scope of supervision is different. SSB only oversees the company to follow sharia principle (Gatot Supramono, 2009).

This different position with similar responsibility in this case does not seem equal. To get deep understanding between SSB and Board of Commissioners, here are the comparisons based on Act of The Republic of Indonesia Number 40 Year 2007 on Limited Liability Company:

\begin{tabular}{|c|c|c|}
\hline COMPARISON & $\begin{array}{l}\text { SHARIA } \\
\text { SUPERVISORY } \\
\text { BOARD }\end{array}$ & $\begin{array}{l}\text { BOARD OF } \\
\text { COMMISSIONERS }\end{array}$ \\
\hline Duty & \begin{tabular}{l}
\multicolumn{1}{c}{ To provide } \\
advice and \\
suggestions to the \\
Board of Directors, \\
as well as to \\
supervise the \\
activities of the \\
Company in order \\
to comply with the \\
syariah principle.
\end{tabular} & $\begin{array}{l}\text { To conduct } \\
\text { supervision over the } \\
\text { management policy, the } \\
\text { implementation of the } \\
\text { management in general, } \\
\text { either regarding the } \\
\text { Company or its } \\
\text { business, and provides } \\
\text { advice to the Board of } \\
\text { Directors. }\end{array}$ \\
\hline Appointment & $\begin{array}{c}\text { The Sharia } \\
\text { Supervisory Board } \\
\text { shall consist of } 1 \\
\text { (one) or more } \\
\text { syariah experts, } \\
\text { appointed by the } \\
\text { General Meeting of } \\
\text { Shareholders based } \\
\text { on the } \\
\text { recommendation of } \\
\text { the Indonesian } \\
\text { Ulama Council } \\
\text { (Majelis Ulama } \\
\text { Indonesia). }\end{array}$ & \begin{tabular}{l}
\multicolumn{1}{c}{ Members of the } \\
Board of \\
Commissioners shall be \\
appointed by General \\
Meeting of \\
Shareholders.
\end{tabular} \\
\hline Responsibility & $\begin{array}{l}\text { The Law of } \\
\text { The Republic of } \\
\text { Indonesia Number } \\
40 \text { Year } 2007 \text { on } \\
\text { Limited Liability } \\
\text { Company does not } \\
\text { explain the } \\
\text { responsibility of the } \\
\text { Sharia Supervisory } \\
\text { Board. }\end{array}$ & $\begin{array}{l}\text { The Board of } \\
\text { Commissioners shall be } \\
\text { responsible to supervise } \\
\text { the Company. } \\
\text { - Each member of the } \\
\text { Board of } \\
\text { Commissioners shall be } \\
\text { obliged with good faith, } \\
\text { prudent and full of } \\
\text { responsibility to } \\
\text { perform his supervisory } \\
\text { duty and provide } \\
\text { advices to the Board of } \\
\text { Directors. } \\
\text { - Each member of the } \\
\text { Board of } \\
\text { Commissioners shall } \\
\text { also be personally liable } \\
\text { for the loss suffered by } \\
\text { the Company if it } \\
\text { resulted from its fault or } \\
\text { negligent in performing } \\
\text { its duties. }\end{array}$ \\
\hline
\end{tabular}




\section{CONCLUSION}

SSB has clear position in Indonesian Laws as the only board in charge to watch SFI to make certain that Sharia Principle is done correctly. Unfortunately, it is not a part of Company Organs because Limited Liability Company Act does not recognize SSB as Company Organs. Company Organs are only the General Meeting of Shareholders, the Board of Directors, and the Board of Commissioner.

Furthermore, the separation of sharia supervision and general supervision causes the different position and responsibilities in the Company between SSB and Board of Commissioners. In fact, SFI must follow both sharia principle and Indonesian Laws, so company cannot separate sharia supervision and general supervision. This paper proposes the unification of supervision in SFI. Therefore, SSB becomes part of Company Organs and has legal position as Board of Commissioners. Legislative Assembly should revise the Act of Limited Liability Company to put SSB as a part of Company Organs. To be more efficient, General Meeting of Shareholders can appoint a person of SSB as Board of Commissioners so the company does not need to spend much money for supervision.

\section{REFERENCES}

[1] BI Sharia Commercial Bank Regulation, Number 11/3/PBI (2009)

[2] Gatot Supramono. (2009). Hukum Perseroan Terbatas. Jakarta: Penerbit Djambatan.

[3] Guidelines for the Implementation of Duties and Responsibilities of the Sharia Supervisory Board of Sharia Rural Bank, Circular Letter of BI Number 15/22/DPbS (2013)

[4] Hichem Hamza, (2013). Sharia Governance in Islamic Banks: Effectiveness and Supervision Model. International Journal of Islamic and Middle Eastern Finance and Management, Vol. 6 Issue: 3, pp.226237, https://doi.org/10.1108/IMEFM-02-2013-0021

[5] Hussein M. Rababa'ah and Yousuf Muhammad Rababa'ah, (2016). The Significance of the Islamic Law (Shari'a) Supervison of the Islamic Banks: The Jordan Islamic Bank as a Model. Journal of Islamic Studies and Culture: June 2016, Vol. 4, No. 1, pp. 164-176

[6] Insurance Act, Indonesia Number 40 (2014)

[7] Limited Liability Company Act, Indonesia Number 40 (2007)

[8] Malek Marwan Yousef Injas, Mohamad Sabri Haron, Rashila Ramli and Raghad Azzam Injas, (2016). The Importance of Shari'ah Supervisory Boards in the Islamic Banking System. South East Asia Journal of Contemporary Business, Economics and Law, Vol. 9, Issue 2 April.

[9] OJK Implementation of Sharia Principles in the Capital Market Rule, Number 15 (2015)

[10] OJK Sharia Capital Market Expert Rule, Number 16 (2015)

[11] Sharia Banking Act, Indonesia Number 21 (2008) 